\title{
Karolina Król*
}

ORCID: 0000-0003-4082-2183

Uniwersytet im. Adama Mickiewicza w Poznaniu

\section{MOTYW AHASWERA \\ W TWÓRCZOŚCI ALEKSANDRA WATA. \\ OD FIGURY ZBIOROWOŚCI \\ DO ZNAKU JEDNOSTKOWOŚCI}

\begin{abstract}
Artykuł stanowi analizę motywu Żyda Wiecznego Tułacza w twórczości Aleksandra Wata. Autorka sięga po teksty, które w dotychczasowych badaniach dotyczących tego tematu były pomijane. Ważną część refleksji na temat motywu Ahaswera stanowią listy do żony oraz notatnikowe zapisy poety. Postać Żyda Wiecznego Tułacza w twórczości Aleksandra Wata przechodzi drogę od figury zbiorowości do znaku losu jednostki. Ahaswer staje się jedną z figur kultury, które Wat czyta przez pryzmat swojego życia. Z czasem w twórczości Wata Ahaswer zostaje obdarzony poczuciem winy i koniecznością odpokutowania swoich grzechów. Chronologicznie ostatnie teksty dotykające tej problematyki pozwalają na podjęcie próby interpretowania postaci Ahaswera jako figury nowoczesnej.
\end{abstract}

Słowa kluczowe: nowoczesność, Aleksander Wat, Żyd Wieczny Tułacz, Ahaswer, Sny sponad Morza Śródziemnego, notatniki Aleksander Wat, listy Aleksander Wat

\section{WSTĘP}

Czesław Miłosz w szkicu poświęconym Aleksandrowi Watowi zawartym w Prywatnych obowiąkach pisze: „Nie, prawdy o naszej epoce nie przekaże żadna epopeja, żadna Wojna i pokój, żadna dogłębna socjologiczna analiza. Błyski, urwane słowa, krótkie sentencje - to najwyżej" (Miłosz 2001: 83).

Z tysięcy błysków i urwanych słów składa się dzieło Aleksandra Wata, o którym napisano już dziesiątki monografii, rozdziałów w pracach zbiorowych i tekstów zamieszczonych w czasopismach. Mimo że istnieje obszerna literatura przedmiotu, niektóre wątki nie zostały dokładnie przeanalizowane. Jednym z motywów, któremu warto poświęcić więcej uwagi, jest historia Żyda Wiecznego Tułacza, zwanego także Ahaswerem.

* Autor do korespondencji: Karolina Król, Uniwersytet im. Adama Mickiewicza w Poznaniu, Instytut Filologii Polskiej, ul. Fredry 10, 61-701 Poznań; e-mail: karolina.krol98uam@gmail.com 
Postać ta pojawia się w twórczości Wata zarówno we wczesnych utworach, jak i tekstach późniejszych. Najobszerniejszą realizacją tego tematu jest opowiadanie Żyd wieczny tułacz (Wat 1960: 9-26). Imię wędrowca pojawia się także w innym utworze z tego samego cyklu - w opowiadaniu Królowie na wygnaniu (Wat 1960: 103). Ważne nawiązania do postaci Ahaswera przynosi także cykl wierszy Sny sponad Morza Śródziemnego (Wat 1992: 288-298) oraz utwór Przemiany (Wat 1992: 162). Wzmianki o Ahaswerze znajdziemy wreszcie w Dzienniku bez samogłosek (Wat 1990a: 124) oraz w listach do żony (Wat 2005: 632, 649-650), a także w notatnikowych zapisach Wata, które ukazały się drukiem po jego śmierci w 2015 roku (Wat 2015: 316 i 418). W dotychczasowej refleksji nad interesującym mnie motywem nie zestawiano ze sobą wszystkich wymienionych utworów poety ${ }^{1}$. Dlatego chciałabym, czytając w porządku chronologicznym przedstawiony wyżej korpus tekstów, prześledzić, jakim przemianom w twórczości Wata ulegał motyw Żyda Wiecznego Tułacza.

\section{AHASWER - ŻYD WIECZNY TUŁACZ}

Na legendę o Ahaswerze składają się dwa podania, które na przestrzeni wieków połączyły się w jedną całość: historia o Malcheusie i opowieść o świętym Janie (Anderson 1965: 11).

Pierwsza z tych legend opowiada o pojmaniu Jezusa w Ogrójcu, a konkretnie o scenie opisanej w Ewangelii wedtug Świętego Jana [18,4]. Apostoł Piotr, stając w obronie swego nauczyciela, obciął mieczem ucho jednego ze strażników mających pojmać Chrystusa. Okaleczonym w ten sposób mężczyzną był właśnie Malcheus. Postać ta pojawia się także później, w opisie sądu Jezusa przed Piłatem. Mimo że w Biblii nie zostało powiedziane wprost, czy mężczyzną poganiającym Chrystusa i policzkującym go jest Malcheus, w legendzie przetrwało przekonanie o tożsamości obu osób.

Druga historia dotyczy postaci Świętego Jana. Według tej legendy zmartwychwstały Jezus przyszedł do apostołów i obwieścił im, że wśród nich znajduje się osoba, która nie umrze, dopóki nie powróci Zbawiciel. Opowiada o tym następujący fragment Ewangelii według Świętego Mateusza [16,28]: „Zaprawdę powiadam wam: Są niektórzy z tych, co tu stoją, którzy nie zaznają śmierci, aż ujrzą Syna Człowieczego przychodzącego w królestwie swoim" (cyt. za: Piotrowski 2008: 65). Z Ewangelii wedtug Świętego Jana [21,20] można wywnioskować, że wspomnianą osobą był Święty Jan.

Dzieje Malcheusa zostały spisane około 550 roku przez bizantyjskiego mnicha Jana Moschosa (Anderson 1965: 13). W następnych wiekach legenda ta była przekazywana ustnie i - najprawdopodobniej w okresie krucjat - pojawiła się także w Europie. Ważnym jej elementem było wskazanie winy Malcheusa, który uczestniczył w procesie skazania Jezusa na śmierć. Połączyła się ona w jedno z opowieścią o Świętym Janie (której kluczowym wątkiem była informacja o długowieczności mężczyzny).

Wolff-Powęska (2008: 27) wspomina jedynie o Snach sponad Morza Śródziemnego. Piotrowski (1996: 125-127) natomiast pisze jedynie o $\dot{Z} y d z i e$ wiecznym tułaczu, pomijając zupełnie śródziemnomorski cyk1. Cykl ten jest pominięty także w antologii tekstów inspirowanych legendą. Piotrowski umieszcza w niej tylko fragment $\dot{Z} y d a$ wiecznego tułacza (2008: 235-236). W dwóch tekstach Prokop-Janiec podejmujących temat Ahaswera pojawia się wzmianka o Żydzie wiecznym tułaczu, jednak w żadnym z nich nie ma odniesień do Snów sponad Morza Śródziemnego (Prokop-Janiec 1992: 74-84; 2001: 120-134). 
Momentem przełomowym w formowaniu się legendy o Żydzie Wiecznym Tułaczu była pierwsza drukowana postać tej opowieści pochodząca z 1602 roku - Kurze Beschreibung und Erzehlung von einem Juden mit Namen Ahasuerus (Piotrowski 1996: 25). Piotrowski twierdzi, że to od niej „rozpoczyna się powszechne spopularyzowanie legendy w Europie” (Piotrowski 1996: 24) i w ten sposób powstała opowieść o Żydzie Wiecznym Tułaczu, która w następnych wiekach wielokrotnie powracała w literaturze.

William Fredric Bowen wyróżnia cztery typy nawiązań do postaci Żyda Wiecznego Tułacza (Bowen 1970: 90-91). Pierwszy z nich, religijny, charakteryzuje się odniesieniami do historii biblijnej i wątków związanych ze znieważeniem Chrystusa. Drugi koncentruje się na postaci Ahaswera jako świadka dziejących się wydarzeń. Trzeci typ nawiązań skupia się na wątkach związanych z żydowskością, natomiast czwarty, najbardziej uniwersalny, dotyczy refleksji na temat ludzkiego cierpienia i ogólnej kondycji wygnańca.

Odniesienia do postaci Ahaswera pojawiające się w twórczości Wata również oscylują wokół tych czterech wyszczególnionych przez Bowena wątków, jednak w późniejszych tekstach wyraźnie dominują dwa ostatnie. Motyw Żyda Wiecznego Tułacza przechodzi drogę od figury tego, co zbiorowe, do znaku indywidualnych przemyśleń jednostki.

W opowieściach z Bezrobotnego Lucyfera na pierwszy plan wysuwa się refleksja dotycząca historii. Wat nawiązuje do postaci Ahaswera w sposób charakterystyczny dla początków XX wieku, pozbawiając bohatera znamion religijności (choć jednocześnie Żyd Wieczny Tułacz ulega kolejnym ideologicznym „konfesjom”). Poeta inspiruje się także wątkami anstysemickimi, próbując pokazać absurdalność stereotypów dotyczących Żydów.

W późniejszych odniesieniach Wata do historii Żyda Wiecznego Tułacza akcenty zostają przesunięte. Poeta zaczyna patrzeć na tę figurę przez pryzmat własnego życia, a nie, jak wcześniej, odnosząc się do niej przy okazji opowiadania historii mówiących o ideach kształtujących zbiorowość. Nie utożsamia się z Ahaswerem, jednak próbuje czytać literaturę przez własne życie, podkreślając plan egzystencjalny opowieści. Odniesienia do tematyki związanej z historią tracą na znaczeniu. Postać Ahaswera staje się kolejną z figur kultury, przez które Wat interpretuje swój los. Poeta snuje także refleksje dotyczące własnej relacji wobec żydowskości oraz kondycji więźnia sowieckiego systemu, zesłańca i w końcu emigranta.

Figura Ahaswera w pewnym aspekcie przechodzi u Wata odmienną drogę od tej opisanej przez Leschnitzera. Badacz zwraca uwagę na zanik odniesień religijnych i oderwanie tej historii od biblijnych korzeni. Wat natomiast z czasem obdarza Żyda Wiecznego Tułacza poczuciem winy i koniecznością pokuty za własne grzechy, łącząc tę postać w pewnej mierze $\mathrm{z}$ eschatologią judeochrześcijańską. W sowieckich więzieniach rodzi się u poety poczucie winy za grzechu komunizmu. Wątek ten wielokrotnie powraca w twórczości autora Mojego wieku, a Ahaswer w późniejszych utworach Wata również nie jest wolny od narastającego przekonania o własnej grzeszności (Leschnitzer 1986: 232).

\section{WAT I SŁONIMSKI. MOTYW AHASWERA W PRZEMIANACH}

Kluczowy w myśleniu o motywie Żyda Wiecznego Tułacza jest powstały w 1924 roku utwór Przemiany. Tekst ten jest najprawdopodobniej pierwszą w twórczości Aleksandra Wata próbą konwersacji z tym kulturowym wątkiem. Można zaobserwować w nim tendencję 
charakterystyczną także dla chronologicznie ostatnich realizacji tego motywu. W przeciwieństwie do opowieści z Bezrobotnego Lucyfera - w Przemianach (teksty te dzielą dwa lata) Wat nie pisze o Ahaswerze jako reprezentancie pewnej zbiorowości. Mianem Żyda Wiecznego Tułacza w tym utworze określona zostaje konkretna osoba - Antoni Słonimski². W Przemianach mamy zatem do czynienia w pewnej mierze z wykorzystaniem motywu Ahaswera do charakterystyki jednego ze skamandrytów. Czytamy:

W zeszłym roku o zwykłej wieczornej godzinie siedziałem w Ziemiance z świetnym poetą Stanisławem Bruczem („Nie ma mglistych Londynów, Londyn jest tylko jeden”) i rozmawialiśmy, jak zwykle, o poezji, o sztuce, o naszych kolegach.

Nagle osłupiałem! Przy sąsiednim stoliku - przy którym siedział i od którego (pamiętam to dobrze) nie odchodził Antoni Słonimski - teraz widziałem twarz inną, niezwykłą! nie twarz - ocean cierpienia, niebo łagodności, gwiazdę mądrości, noc dobroci! Była to nieprawdopodobnie znużona, wielowiekowa wschodnia twarz Żyda, której łagodność, której znużenie i dobroć bez granic oślepiały i wzruszały mnie niezmiernie.

Oszołomiony - (wszak zbyt dobrze pamiętałem jeszcze przed sekundą uśmiechającą się stamtąd miłą, dowcipną, zblagowaną twarz Słonimskiego) - nie zdając sobie sprawy z własnych ruchów, podniosłem się i wyciągnąłem doń rękę.

Uścisnął ją, i lekko skinąwszy głową, przedstawił się:

„Ahaswer, Żyd wieczny tułacz” (Wat 1992: 162).

W utworze tym pojawiają się wątki autobiograficzne związane ze znajomością obu poetów. W latach poprzedzających powstanie tego utworu mieli oni dość napięte relacje - Słonimski wielokrotnie dawał wyraz swojej niechęci do futurystów, w tym do autora Piecyka (Kuciel-Frydryszak 2012: 50).

Kwestią sporną był w dużej mierze stosunek do własnej tożsamości. Obaj poeci byli zasymilowanymi Żydami, jednak ich podejście do własnego pochodzenia różniło się diametralnie. Słonimski, choć postulował postawę tolerancyjną, pisał teksty niepochlebne wobec Żydów. W 1924 roku, czyli w roku publikacji wiersza Wata, pojawia się tekst Słonimskiego O drażliwości Żydów; w tym samym roku poeta pisze też recenzję Mechano-bzdura niewolną od inwektyw kierowanych pod adresem społeczności żydowskiej (Graf 2018: 274-300).

Kontekst znajomości ze Słonimskim jest o tyle ważny dla interpretacji motywu Ahaswera, że w Przemianach zarysowuje się tendencja charakterystyczna dla późniejszych Watowskich realizacji tego motywu - skupienie na jednostce i jej stosunku do własnej niejednoznacznej i problematycznej tożsamości.

2 Co ciekawe, Słonimski w 1943 roku napisał wiersz Ahaswer, w którym tytułowa postać staje się ,uniwersalną figurą losu tułacza” (Panas 1996: 138). Wiersz Słonimskiego brzmi następująco: „Ja już tej wojny nie wygram,/ Serca już nie wyrwę z kleszczy./ Uciekam - zbieg i emigrant,/ Jak uciekałem z Zaleszczyk./ Uciekam drogą zawiłą, / Od własnych uciekam wspomnień/ Jak ten co siadł nad mogiłą/ I szuka gwiazd nieprzytomnie./ Skulony, skryty w fotelu, / Czujny dezerter ze świata,/ W małym londyńskim hotelu/ Węzły gordyjskie rozplatam./ Patrzący w popioły wygasłe,/ Pledem okryty jak chustą,/ Strudzony biegiem Ahaswer,/ Owijam, otulam się pustką" (Słonimski 1964: 463). 


\section{OPOWIEŚCI Z BEZROBOTNEGO LUCYFERA}

Analizując motyw Ahaswera w twórczości Wata, badacze najczęściej interpretują utwór zatytułowany $\dot{Z} y d$ wieczny tułacz. Przedstawiona w nim historia opowiada o wydarzeniach rozgrywających się na przestrzeni kilkuset lat - od początku XX wieku aż do wieku XXIX, zatem łączy porządek czasu współczesnego autorowi z futurologią.

Najważniejsza wydaje się jednak kompozycyjna rama całej opowieści, wyznaczona przez dwa podobne do siebie wydarzenia, dzięki którym historia zatacza koło. Młody Żyd, Natan z Zebrzydowa, studiuje Torę. Pewnego dnia chce prosić rebego o radę, więc dogania go, chcąc porozmawiać. Mężczyzna odwraca się, a Natan ,[...] z przerażeniem zamiast żółtaczkowatej, piegowatej twarzy rebego zobaczył rumianego, lnianowłosego i niebieskookiego proboszcza" (Wat 1960: 13).

Po tym wydarzeniu Natan odkrywa, że jego edukacja była możliwa dzięki finansowemu wsparciu bogatego barona Goulda. Wdzięczny, postanawia odnaleźć swojego dobroczyńcę, porzucając naukę. Gdy dochodzi do spotkania z Gouldem, Natan ujawnia swój polityczny, a nie religijny cel - chciałby sfinansować światową rewolucję komunistyczną.

Mężczyzna wielokrotnie ulega gwałtownym ideowym przemianom, aż w końcu zostaje papieżem. W międzyczasie w społeczeństwie nasilają się kolejne podziały. Wybucha i kończy się wojna, jednak konflikty nie zostają zażegnane. Wszystkie kościelne posady zostają przejęte przez Żydów. Antysemici nie potrafią się z tym pogodzić i stają się największymi wrogami systemu oraz nowego ustroju.

W następnych wiekach próbowano narzucać nowe wiary i nakładać represje na społeczeństwo niepoddające się restrykcjom. Ponadto nastąpiło wiele absurdalnych z punktu widzenia historii wydarzeń, polegających na ponownych konwersjach religijnych, inkwizycjach i wojnach.

Przełomowy okazuje się rok 2900, kiedy to historia zatacza koło i drugi, mieszkający w Zebrzydowie Natan szuka pomocy u swego nauczyciela, który okazuje się jednak kimś innym. Choć od podobnego wydarzenia minęło prawie tysiąc lat, niewiele się zmieniło. Zarówno Natan z początku XX wieku, jak i Natan z przyszłości stracili rodziców w pogromie. Rodzice pierwszego z bohaterów zginęli w zamieszkach skierowanych przeciwko Żydom. Prawdopodobnie to samo stało się z rodziną drugiego z Natanów, który oddawał się studiowaniu Talmudu. Choć w wykreowanej przez Wata historii Żydzi tracą i odzyskują swoje prawa, żadne zmiany w ich postrzeganiu nie zachodzą raz na zawsze. Historia się powtarza i czytelnik może spodziewać się, że w następnych stuleciach opowieści nastąpiłyby kolejne rewolucje, spiski i wojny, niewiele mające wspólnego z roztrząsaniem zawiłości religijnych czy jakąkolwiek racjonalną logiką.

Postać Ahaswera nie pojawia się w opowiadaniu w postaci osobowego bohatera. Jedyne (poza tytułem utworu) bezpośrednie przywołanie legendy ma miejsce w szczególnym - bo wyodrębnionym dzięki szkatułkowej kompozycji - fragmencie opowieści, którym jest list Natana do barona Goulda. O tym, w jaki sposób Wat nawiązuje do historii o Ahaswerze, pisano już kilkukrotnie ${ }^{3}$, zatem chciałabym skupić się na innych realizacjach tego motywu, zazwyczaj pomijanych w opracowaniach.

\footnotetext{
3 Zob. między innymi studium Prokop-Janiec (1992),„Żyd wieczny tułacz”. Dialektyka, publicystyka, katastrofa.
} 
W Królach na wygnaniu interesujący mnie wątek jest zarysowany słabiej niż w pochodzącym z tego samego tomu Żydzie wiecznym tułaczu. Opowieść przedstawia historię niedawno odkrytej Wyspy Królów, leżącej nieopodal Madagaskaru. Na ten niezbadany kawałek lądu zostają wysłani zdetronizowani monarchowie rządzący niegdyś różnymi europejskimi mocarstwami. Historia zaczyna biec jak gdyby odwrotnie - postęp umysłowy i cywilizacyjny zostaje zastąpiony przez zamiłowanie do zabobonów, a kapitalizm wypiera system feudalny. Równocześnie, niejako dla ustabilizowania powrotu do archaicznych form społeczno-gospodarczych, wokół wyspy wyłaniają się niebezpieczne rafy, które na stulecia odcinają ją od świata zewnętrznego. Ląd zostaje zapomniany na lata. Europa przypomina sobie o jego istnieniu dzięki odkrytej w 2431 roku wzmiance o tajemniczej wyspie.

Jedną z postaci występujących w Watowskiej opowieści jest dziennikarz Tomasz Clark, który fascynuje się obserwowaniem absurdów i przypadków wpływających na bieg historii. Ciągle zmienia poglądy (w czym przypomina Natana z Żyda wiecznego tułacza), dzięki czemu idealnie sprawdza się w pracy korespondenta wojennego. Tomasz zdaje relacje z pola bitwy, będąc sojusznikiem aliantów, później zaś bez oporów przejmuje stanowisko niegdysiejszego wroga. Doświadczony przez życie, przeżywa wiele przygód - między innymi trafia do niewoli bolszewickiej, a później ucieka do Mongolii. Mężczyzna przemieszcza się po świecie, nigdzie nie czując się do końca u siebie. To właśnie on w jednym z fragmentów zostaje nazwany imieniem Żyda Wiecznego Tułacza:

Ale tylko najbliżsi przyjaciele znali istotny motor jego [Tomasza - przyp. K.K.] rozpędu. To szczególna patologiczna namiętność: niczym nieposkromione pragnienie posiadania kobiet wszystkich narodów i plemion - uczyniło z Tomasza niestrudzonego Ahaswera prasy. W trzydziestym piątym roku życia Tomasz mógł chełpić się bliskimi stosunkami z setką narodów i szczepów. Jego pesymizm polityczny brał początek z ograniczonej liczby grup etnicznych. Aby posiąść cuchnącą karliczkę z plemienia Pigmejów lub olbrzymią ogrodniczkę Matabele, nie zawahał się odbyć dalekich podróży do Kafrów. W pogoni za ostatnią kobietą czerwonoskórego szczepu Sioux-Ogallalla, występującą w music-hallu londyńskim, przybył do Anglii i tu wywietrzył tajemnice statku „Cromwell” (Wat 1960: 103).

Nawiązanie do postaci Żyda Wiecznego Tułacza jest w powyższym fragmencie ledwie zarysowane - pojawia się jako element charakterystyki Tomasza Clarka. Ahaswer w Królach na wygnaniu, podobnie jak w Żydzie wiecznym tułaczu, jest figurą wyłączoną z kontekstu religijnego powiązanego z ewangeliczną historią. Wątek Ahaswera zostaje tu wprowadzony najpewniej jako nośnik ironicznej oceny. O ile bowiem Żyd Wieczny Tułacz był świadomy własnych korzeni, o tyle Tomasz Clark, dzisiejszy „Ahaswer prasy”, podobnie jak tytułowy bohater zbioru opowieści, czuje się zagubiony w nowoczesnym świecie, pozbawionym trwałych fundamentów wiary. Sam też, zmieniając mocodawców i stronnictwa, przyczynia się do rozwoju postaw z jednej strony ideologicznych, z drugiej pragmatycznych, bo powiązanych z doraźną korzyścią ,,wyznawcy” coraz to innych światopoglądów. Wiara zostaje tu zastąpiona ideologią, co staje się także rysem charakterystycznym biografii Wata. 


\section{MOTYW AHASWERA W EPISTOLOGRAFII POETY}

Następne dziesięciolecia po napisaniu Bezrobotnego Lucyfera to czas braku poetyckiej aktywności autora Piecyka i okres jego zaangażowania w życie literackie oraz kwestie społeczno-polityczne.

Choć Wat jako poeta przez dziesięciolecia nie publikował swoich wierszy, cały czas pracował nad kolejnymi tekstami. Prowadził także korespondencję oraz notatnikowe zapiski, w których pojawiają się przemyślenia będące później zaczątkiem utworów poetyckich. Badacze wielokrotnie zauważali, że twórczość Wata warto czytać w całości jako jedno wielkie, niedokończone dzieło, w którym poszczególne wątki wielokrotnie pojawiają się w różnych konfiguracjach (Pietrych 2017: 116).

Postać Żyda Wiecznego Tułacza również powraca w twórczości autora Bezrobotnego Lucyfera. Warto podkreślić, że Ahaswer jest obecny zarówno w utworach publikowanych za życia Wata, jak i w listach oraz prywatnych zapiskach pozostających w notatnikach. Świadczy to o wielokrotnym podejmowaniu namysłu nad losem tej postaci i uczynieniu z niej ważnego przedmiotu refleksji.

Motyw Żyda Wiecznego Tułacza występuje między innymi w prywatnej korespondencji poety. W listach do żony z 1949 roku Wat dwukrotnie nawiązuje do postaci Ahaswera. Po raz pierwszy w liście do Oli Watowej napisanym 5 lutego 1949 roku przywołuje biblijną historię z Księgi Estery, na pamiątkę której obchodzone jest święto Purim"

\section{Kochanie!}

Przyjeżdżaj! Bądź jednak przygotowana na surowy reżym: trochę jak królowa Esther z Ahaswerem. Nie miała prawa do niego się odezwać, dopóki on sam nie zagadnął jej lub nie dał znaku berłem. Ale przecież Ahaswer kochał Esterę, i Esther Ahaswera (Wat 2005: 632).

Druga wzmianka o Ahaswerze, pojawiająca się w liście z 29 września 1949 roku, nie odnosi się już do biblijnego rodowodu postaci. Wat wyraźnie pokazuje, że w jego wyobraźni literatura i kultura splata się z autobiografią:

Jedyna moja

Od niedzieli jestem w Rzymie. Rozdarty między gwałtownym pociągiem do Was do domu a chciwością i ciekawością świata, no i wyrachowaniem. - Żyd wieczny tułacz w Rzymie - gdzie zresztą ma być, jak nie w Rzymie? Pomyśleć: w ciągu trzech lat - Pamir i Kapitol. [...] Oczywiście, nie szukam motyli pod Łukiem Tytusa, mimo tego piękna ogarnęła mnie jakaś spóźniona mocno, przelotna nienawiść, kiedy na wewnętrznym reliefie zobaczyłem sześcioramienny jerozolimski świecznik - tym bardziej że pierwszy jeniec za świecznikiem bardzo jest podobny do mojego ojca (Wat 2005: 649-650).

4 W tym miejscu warto przytoczyć myśl Andersona, który uważał, że najprawdopodobniej imię Ahaswer pojawiające się w kanonicznych wersjach legendy o Żydzie Wiecznym Tułaczu zostało zainspirowane obchodami święta Purim (Anderson 1965: 50). 
Warto zwrócić uwagę na dwa wątki, które pojawiają się w powyższym fragmencie i które będą charakteryzować późniejsze Watowskie nawiązania do motywu Ahaswera: skupienie na własnej relacji z żydowskością oraz poczucie bycia wygnańcem.

W liście do żony obecna jest zapowiedź refleksji związanych z poczuciem niezakorzenienia i wyobcowania. Wat wspomina o rozłące z żoną spowodowaną wyjazdem do Wenecji na kongres Pen-Clubu, a następnie do innych włoskich miast. Obserwacja tamtejszych zabytków kultury stała się inspiracją do własnych poszukiwań artystycznych.

Wzmianka o Łuku Tytusa pojawia się w twórczości Wata jeszcze przynajmniej dwa razy - w Moraliach (Wat 1990a: 48-49) oraz w cyklu utworów Na melodie hebrajskie (Wat 1992: 211-213). Ten ostatni cykl Wat napisał w tym samym roku, w którym powstały wspomniane wcześniej listy do żony), co świadczy o trwałości i wadze rzymskiego doświadczenia. Poeta notowat:

Mając przejść Bramę Tytusa, której piękno z naszej odległości, na tle nieba obok samotnych kolumn Kastora i Polluksa wstrząsnęło moim sercem - zaparłem się w ziemię jak osioł i: o, barbarzyńca! splunąłem nagłą ogarnięty nienawiścią. Dopiero w chwili następnej przyjrzałem się wewnętrznej płaskorzeźbie, na której przodkowie moi skuci kajdanami, pędzeni w niewolę, niosą menorę jerozolimską, a śród nich, jedna z pierwszych, twarz mojego ojca!... [...] Potem dowiedziałem się, że nigdy jeszcze, od paru tysięcy lat, żaden Żyd (przynajmniej rzymski, a byli wśród nich ludzie najświatlejsi) nie przeszedł tędy - natomiast w dniu ogłoszenia Państwa Izraelskiego Żydzi rzymscy przeciągnęli manifestacyjnie, thumnie, z muzyką, w radości i triumfie (Wat 1990a: 48-49).

\section{ŻYDOWSKA TOŻSAMOŚĆ ALEKSANDRA WATA. AHASWER I POCZUCIE WINY}

W interpretacji powyższych fragmentów przydatny wydaje się klucz biograficzny. Wat należał do grona tych polskich pisarzy, którzy byli zasymilowanymi Żydami. Poeta był świadomy swojego pochodzenia i historii własnej rodziny, obie kultury (polska i żydowska) w jego świadomości współistniały ze sobą, choć żydowska tradycja w pierwszej połowie życia pisarza nie była żywym elementem jego codzienności5.

Sławomir Jacek Żurek wyszczególnia kilka pokoleń żydowskich pisarzy w literaturze polskiej, począwszy od XIX wieku, i stwierdza, że aż do końca XVIII stulecia świecka literatura żydowska prawie nie istniała (Żurek 2004: 11). Dla pierwszych generacji kultura żydowska była ważnym punktem odniesienia. Młodsi twórcy, tacy jak Cezary Jellenta czy Wilhelm Feldman, należący według badacza do czwartej generacji polskich twórców pochodzenia żydowskiego, już od urodzenia (na przełomie lat sześćdziesiątych i siedemdziesiątych XIX wieku) byli wychowywani w duchu asymilacji. Dla kolejnych pokoleń żydowska tradycja

\footnotetext{
5 Por. „Nigdy nie czułem się Polako-Żydem czy Żydo-Polakiem. Nie znosiłem Metysów. Zawsze czułem się i Żydem-Żydem, i Polakiem-Polakiem (jak by się powiedziało po francusku). Jednocześnie trudne do wytłumaczenia, ale prawdziwe. Zawsze byłem dumny (o ile wolno w ogóle być dumnym z przynależności do tej czy innej grupy ludzkiej), że jestem Polakiem, że jestem Żydem. A także zrozpaczony: że jestem Polakiem, że jestem Żydem. Fura nieszczęść!” (Wat 1990a: 19).
} 
była mniej istotnym punktem odniesienia w codziennym życiu, coraz częściej istniejąc w świadomości jedynie jako element pamięci o własnych przodkach.

Żydowskość Wata nie łączyła się z konfesją - była raczej związana z poczuciem przynależności do pewnej tradycji, która dla poprzednich pokoleń rodziny stanowiła bardzo ważny punkt odniesienia. W wielu tekstach poeta odnosi się do starotestamentowych postaci i wyobrażeń. Warto powtórzyć, że z wątkiem dotyczącym żydowskiej tożsamości łączy się w powojennej twórczości Wata trwałe i nasilające się poczucie winy:

Dlaczego podkreślam swoje grzechy, swoje winy? Mówiłem o tym, że za dużo skrupułów sobie robię. Przypuszczam, że tu jeszcze się wypowiada moja żydowskość, rozumiesz. [...] Więc to jest dziedzictwo żydowskie. Generalnie mówiąc, ja ujmuję świat, życie i siebie - to jest niedobre w kategoriach winy i kary. [...] Nie jestem kajający się inteligent ani nie jestem masochistą, tylko po prostu jest to obciążenie żydowskie (Wat 1990b: 300).

Główną przyczyną wyrzutów sumienia był ,grzech komunizmu”, o którym Wat wspomina wielokrotnie, szczególnie w Moim wieku. W naznaczonych autobiografizmem tekstach poeta wielokrotnie dokonuje rozliczenia z samym sobą i własną przeszłością. Targające Watem poczucie winy staje się także ważnym wątkiem w jego literackiej konwersacji z legendą Żyda Wiecznego Tułacza - pojawia się w późniejszym okresie twórczości. Ahaswer występujący w opowieściach pochodzących z Bezrobotnego Lucyfera, Przemianach oraz listach nie interpretuje jeszcze swojego losu jako kary za grzechy. Świadomość własnej odrębności, która wiąże się z poważnymi konsekwencjami, dręczy dopiero bohatera pierwszego utworu z cyklu Sny sponad Morza Śródziemnego:

A droga szła przez rozlewiska oleiste, prawda, że płytkie, lecz noga tapla się w nich ciężko.

Ich barwy przypominają gardła gołębie, gdy po całonocnym chodzeniu

po mieście, o świcie wracałem do ciepła domu, krzepki Ahaswer,

gnany z wyroku, nie ogłoszonego, ale już-już przeczuwalnego (Wat 1992: 288).

Ten autobiograficzny cykl został bardzo dokładnie opisany i zinterpretowany przez Krystynę Pietrych (1999: 107-164), więc nie będę poświęcać mu więcej uwagi. Warto jednak zauważyć, że w przytoczonym fragmencie podmiot liryczny nazywa siebie mianem Ahaswera, targanego wewnętrzną potrzebą błąkania się po okolicy. Jest on wygnańcem, który nie czuje się nigdzie dobrze, choć nigdy nie został oficjalnie skazany na banicję

Żyd Wieczny Tułacz staje się w późnych utworach Wata figurą jednostkowej egzystencji, figurą, którą poeta coraz częściej i bardziej jednoznacznie wykorzystuje do opisu własnego losu. W zacytowanym powyżej fragmencie wiersza wzmianka o wyroku prowadzi nas do

${ }^{6}$ O poczuciu bycia wygnańcem w ciekawy sposób pisała Małgorzata Łukaszuk: „A jest ta poezja właśnie świadectwem pragnienia powrotu. Wygnaniec, tułacz w przestrzeni i czasie łaknie powrotu - innego jednak niż ten, jaki stał się udziałem schodzącego z gór Zaratustry czy Makbeta zdążającego do »nie swojego« domu. Przechodzień na ziemi, której rzeźbę ustanowiła dla groźby wiekuistej Ręka Mściwa, człowiek z wieku hańby, szmatławienia, eksterminacji, zdeprawowania mitów i upadku cywilizacji, dociera nie do kolejnej Arkadii lecz do Łuku Tytusa. Zgodnie z zamiarem wyrażonym w Hymnie, Żówiu - zbiera dane, uzupełnia luki genealogii, i w efekcie odkrywa twarz »srogą« Tytusa, a przede wszystkim - krwawy testament ojca, przeciw któremu niegdyś się zbuntował" (Łukaszuk 1989: 111). 
myśli o jakimś wcześniejszym przewinieniu, za które później podmiot musi odpokutować. Odnajdujemy tu nowy element w Watowskich realizacjach motywu Ahaswera. Poeta powraca do korzeni biblijnej historii, w której, jak pamiętamy, Żyd Wieczny Tułacz wystąpił przeciwko Jezusowi podczas drogi krzyżowej.

Co mogło być przewiną Ahaswera? Czytając utwór w sposób biograficzny, od razu na myśl przychodzi „grzech komunizmu” Wata. Drugim ważnym tropem jest jednak wątek żydowski. Przewiną staje się samo bycie Żydem, które w XX wieku wiązało się ze śmiertelnym zagrożeniem. Ahaswer jest naznaczony niezawinionym piętnem - choć nie uczynił nic złego, okazuje się winny bycia Żydem7. Ten wątek, w pierwszym ze Snów sponad Morza Śródziemnego ledwie zarysowany, staje się szczególnie widoczny w jednym z fragmentów Dziennika bez samogłosek, który został napisany w czasie zbliżonym do momentu powstawania śródziemnomorskiego cyklu:

Sen L... [Lucy Ulrich - przyp. K.K.] w 1938: miała 16 lat, jest pośrodku, a z obu stron dwa pochody biegnących Żydów z tobołkami, Ahaswerów pędzonych ku śmierci i dwaj esesmani, którzy ją chcą odpędzić: „Raus!” (broniono ją wtedy w szkole, była uprzywilejowana, widocznie była bardzo ładna).

Na temat antysemityzmu Wat pisał:

W Polsce antysemityzm idzie od ziemi, we Francji z etnospołecznych źródeł. Polska ziemia nie chce Żydów, odpycha i bodzie. Poza społeczno-etnicznymi powodami antysemityzmu, niewątpliwie silniejszymi niż gdzie indziej, obcość, wrogość ziemi, nie chce ona nosić Ahaswera, prześladowców Jezusa Chrystusa [Paryż, listopad 1963] (Wat 1990a: 124).

Ahaswer znieważył Chrystusa, więc teraz jest prześladowany. Jego historia zostaje wpisana w los dwudziestowiecznych Żydów, przewożonych z miejsca na miejsce, transportowanych do obozów koncentracyjnych i obozów zagłady. Warto jednak podkreślić, że choć Wat pisze o ,pochod[ach] biegnących Żydów z tobołkami, Ahaswerów pędzonych ku śmierci”, ma na myśli nie tylko zbiorowość ludzi o podobnym pochodzeniu, dotkniętych tym samym okrutnym losem. Każda z tych osób jest odrębną jednostką, tak jak wymieniona z imienia i nazwiska Lucy Ulrich, w której obronie stawali nieliczni.

W powyższym fragmencie splatają się wątki religijne (wszak mamy tu do czynienia ze zderzeniem dwóch konfesji) z historycznymi (dwudziestowieczni Ahaswerowie są świadkami okropieństw swojego wieku), tożsamościowymi (wszystkich Żydów Wiecznych Tułaczy łączy ich pochodzenie) oraz uniwersalnymi, związanymi z wyobcowaniem jednostki. Wszystkie wymienione przez Bowena typy nawiązań do historii Ahaswera łączą się w jedną całość, którą można czytać przez pryzmat biografii Wata i historii, w której tworzeniu ma swój udział i której staje się ofiarą.

7 Warto przytoczyć tu spostrzeżenie Łukaszuk: „Tragicznym elementem tej »roli« jest wielokrotnie podkreślona wina - życie, sprowokowane rozpętanym »baletem potencji« z jego wymiennością funkcji: jest się »widzem, zarówno jak autorem,/ kordebaletem, zapewne, lecz także tragicznym solistą (Przed Bonnardem), jest życiem zawinionym, szukającym sankcji we własnych dobrowolnych decyzjach, w nierozumieniu onirycznych znaków, w lekceważeniu snów. Kara jest więc słuszna - poprzedził ją «grzech»: nierozważnych proroctw, bluźnierczych obrzędów, ciekawości eksperymentu, upadku, buntu... Ale los Żyda Wiecznego Tułacza, jak los Odyseusza, Hamleta, Jonasza, Hioba itd. - jest znów cytatem. I karą, która może spotkać jedynie potomka kasty kapłańskiej za przewinę »ucieczki«" (Łukaszuk 1989: 108-109). 


\section{NOTATNIKI. AHASWER JAKO FIGURA NOWOCZESNA}

Wzmianka o Ahaswerze pojawia się także w innych osobistych uwagach Wata, a mianowicie w notatnikowych zapiskach, które powstawały w latach pięćdziesiątych i sześćdziesiątych ubiegłego wieku. Pierwsza ze wzmianek o Ahaswerze znajduje się w czwartym, druga zaś w piątym notatniku. Teksty te są, moim zdaniem, osobnym świadectwem zainteresowania Wata Ahaswerem. Mają charakter ulotnych notatek.

Czwarty zeszyt zawiera - jak głosi odręczny napis na zielonej okładce - ,[c]ytaty i różne M[ateriały?]" (Wat 2015: 292). Pojawiają się w nim fragmenty zapisków w różnych językach, między innymi po polsku, rosyjsku i francusku. Wśród wielu luźnych notatek można znaleźć także fragmenty utworów lub krótkie teksty przepisane w całości, między innymi wiersz Anny Cwietajewej zanotowany z adnotacją „,do Antologii” (Wat 2015: 309).

Imię Ahaswera pojawia się wśród zapisków dotyczących historii Rosji, opatrzonych konkretnymi datami. Starając się oddać notatnikowy charakter tekstu, przytaczam ten fragment $\mathrm{z}$ takim podziałem na poszczególne wersy, jaki widoczny jest w oryginale:

Do kniazia Kurbskiego ${ }^{8} 1564$ uciekł po przegranej

bitwie. Z Litwy wysłał list oskarżycielski

Korespondencja miedzy banitą a carem 1564-1579

Kurbski 4 listy, Iwan 2.

Kurbski domaga się ,synklitu”, rady adm[inistracji] bojarskiej przeciw autokracji

„Nous sommes libres de récompenser nos esclaves, libres

aussi les exécuter" (list z 1564)

str. 72

Saul,

Ahaswer, Joab

Kurbski, że nie wolno niszczyć „les forts en Israël”

Kapłanów danych przez Boga, opierając się na

!! „homoncules guerriers"

„Si vous étiez enfants d'Abraham, vous feriez

aussi les auvres d'Abraham. Mais de

ces pierres Dieu peut susciter une postériorité

pour Abraham" / w 1564 (Wat 2015: 316).

8 Andrzej Kurbski był księciem moskiewskim i zaufanym współpracownikiem cara Iwana IV. W 1564 roku przystał na propozycję podwładnych króla Zygmunta Augusta, przechodząc na służbę polskiego władcy. Decydując się na zdradę, przyczynił się do śmierci całej swojej rodziny - jego matkę, żonę i syna zgładzono w więzieniu. W 1979 roku wysłał list do Iwana IV (Kotarski: dokument online).

9 W thumaczeniu na język polski francuskie fragmenty brzmią następująco: „Wolno nam wynagradzać naszych niewolników, wolno/ nam też ich zgładzić. (Nous sommes libres de récompenser nos esclaves, libres/ aussi les exécuter.) [...] nie wolno niszczyć »fortów/ silnych [ludzi] w Izrealu« [z frazy jednoznacznie nie wynika]» (,les forts en Israël”) [...] opierając się na !! »walecznych homunkulusach«/ „Gdybyście byli dziećmi Abrahama, czynilibyście/ również dzieła Abrahama. Lecz z tych kamieni/ Bóg może stworzyć Abrahamowi potomstwo«" (,,homoncules guerriers”/ „Si vous étiez enfants d'Abraham, vous feriez/ aussi les auvres d'Abraham. Mais de/ ces pierres Dieu peut susciter une postérioritél pour Abraham"). Za pomoc przy thumaczeniu tekstu bardzo dziękuję dr. Krzysztofowi Hoffmannowi. 
Kolejny raz imię Ahaswera pojawia się w notatniku piątym wśród luźnych notatek dotyczących historii i kultury:

Kierkeg[aard], Ou bien... ou bien...

Gallimard, 1943

Enten-Eller

$=$ Victor Eremita $^{10}$, Johannes de Silentio, Vigilius

Haufniensis, Johannes Climacus (prow[adzili] życie religij[ne]

estetyk - żyje w chwili (z tym Don Juan, Faust, Ahasverus

moralista - w czasie, w tristium życia

religia - w stos[unku] z wiecznością, chiliasmus nie zawsze tylko w związku $\mathrm{z}$ wiecznoś[cią]

(Wat 2015: 419).

Powyższe fragmenty warto czytać obok siebie, wszak oba są jedynie scenariuszami opowieści, które miały wypełnić zapewne planowane dopiero dzieła. Postać Żyda Wiecznego Tułacza zostaje wpisana $\mathrm{w}$ tych notatkach w szeregi postaci, figur, które połączone miały pozwolić pisarzowi, jak możemy się domyślać, opowiedzieć o istotnych kierunkach ewolucji kultury i cywilizacji europejskiej. Wat, wymieniając w tych szeregach Ahaswera, czyni tę postać znakiem zmian dokonujących się w odziedziczonym i zmieniającym się na jego oczach świecie. Zanotowanie imienia Ahaswer obok wzmianki o postaciach, takich jak Don Juan czy Faust, których losy przywoływany przez Wata Kierkegaard uważał za przykład życia estetycznego (Mazurkiewicz 2005: 114-115), sugeruje pewne podobieństwo pomiędzy wszystkimi tymi osobami. Być może wynika ono z ciągłego poczucia niezaspokojenia i wyobcowania, które łączy wymienionych trzech mężczyzn. Wzmianka o Kierkegaardzie stwarza możliwość zastanowienia się nad tym, jak Wat określiłby życie Ahaswera - czy byłby to przykład życia estetycznego, etycznego, a może religijnego?

Wprawdzie Wat zapisuje imię Żyda Wiecznego Tułacza w tej samej linii, w której znajduje się skrót myślowy dotyczący sensu Kierkegaardowskiej refleksji o życiu estetycznym, jednak nie pojawia się tutaj wyraźne stwierdzenie, że Ahaswer jest według poety przykładem osoby będącej na tym właśnie etapie życia. Biorąc pod uwagę ewolucję, jakiej podlega Żyd Wieczny Tułacz w twórczości Wata, można skłaniać się ku widzeniu tej postaci jako bardzo niejednorodnej i przechodzącej przez różne stadia opisane przez Kierkegaarda. To wątek, który wymaga dalszych badań i zasługuje na osobne opracowanie.

Szczególnie ciekawe może okazać się zestawienie Żyda Wiecznego Tułacza z Faustem targanym poczuciem niezaspokojenia. Opowieść ta jest według Marshalla Bermana jedną z pierwszych historii nowoczesnych. Badacz przedstawia dzieje Goethowskiego Fausta jako trzy przemiany głównej postaci Marzyciela w Kochanka, a następnie w Developera (Berman 2006: 52). Trzecia z tych odsłon jest, według Bermana, zapowiedzią działań systemów totalitarnych. Faust chce stworzyć nowy porządek, nie licząc się z tym, że będzie się on wiązał z zagładą staruszków, Filemona i Baucis (Berman 2006: 85-91). Druga część Fausta Goethego przez Manfreda Ostena jest interpretowana także jako opowieść nowoczesna. Badacz

10 Warto przypomnieć, że Victor Eremita, Johannes de Silentio, Vigilius Haufniensis oraz Johannes Climacus to pseudonimy Kierkegaarda. 
uważa, że Faust jest ogarnięty „lucyferowym pośpiechem” i jego pochopne dążenie cechują nowoczesne niekonsekwencje ${ }^{11}$. Będąc osobą niecierpliwą i bardzo ciekawą świata, bohater Goethego próbuje stworzyć homunkulusa - człowieka z probówki.

Sądzę, że Faust Goethego jest ważnym kontekstem w interpretacji przytoczonego fragmentu Notatników Wata. Wzmianka o „walecznych homunkulusach” (homoncules guerriers), których nie można wykorzystywać do niszczenia „fortów/ silnych [ludzi] w Izrealu” (les forts en Israël) (Wat 2015: 316) być może świadczy o sprzeciwie wobec nowoczesności, której jednym z projektów była eugenika służąca udoskonaleniu człowieka - idea owocująca między innymi Zagładą. Oczywiście, Wat najprawdopodobniej cytuje fragmenty listów Kurbskiego do cara Iwana, jednak wyimki te znajdują się w Notatnikach obok imion biblijnych postaci. Można zatem pokusić się o interpretację całego zestawienia notatek, odrywając je od pierwotnego kontekstu konfliktu kniazia z carem.

Saul, Ahaswer i Joab są postaciami biblijnymi. O ile Saula i Joaba można jednoznacznie określić jako Żydów, o tyle postać Ahaswera może sprawiać problemy. Jeżeli zostanie ona interpretowana zgodnie z tradycją, będzie Żydem Wiecznym Tułaczem, którego historia została zapoczątkowana w Biblii, jednak pod zupełnie innym imieniem (Malcheus). Jeżeli natomiast wzmianka o Ahaswerze będzie interpretowana jako napomknienie o postaci biblijnej pojawiającej się w Księdze Estery, wówczas osoba ta będzie kojarzona z perskim królem, skonfliktowanym z narodem żydowskim ${ }^{12}$. Myślę, że ta niejednoznaczność jest wpisana w tekst Wata. Ahaswer w Notatnikach funkcjonuje jako element kultury europejskiej. Wat powraca do biblijnych korzeni tej postaci, z jednej strony zwracając uwagę na jej podobieństwo do innych osób, z drugiej zaś nie rezygnując z podkreślania jednostkowości bohatera legendy. Wszak w zależności od tego, który Ahaswer zostaje wymieniony z imienia, interpretacja notatnikowych fragmentów będzie wyglądać inaczej.

Nie ma wątpliwości, że poeta intensywnie rozmyślał nad losami tej postaci. Oba fragmenty Notatników są kolejnym dowodem na to, że historia Ahaswera należała do ważnych dla Wata motywów i figur. Sądzę, że wątek związany z Żydem Wiecznym Tułaczem byłby ważnym komponentem Gesamtkunstwerk, którego napisanie Wat planował przez całe życie. Notatniki zawierają istną kopalnię motywów i pomysłów mogących w przyszłości stanowić zaczątek takiego dzieła (Pietrych 2017: 120).

Gdyby Watowi udało się zrealizować plany, być może w owym Gesamtkunstwerk, znalazłby się także wątek związany z Ahaswerem. Żyd Wieczny Tułacz jako postać pozwalająca odnieść się do najważniejszych rysów człowieka i ogarniającej go historii, wspólnoty i jednostki, kultury i cywilizacji europejskiej, a także religii, mógłby zajmować w dziele ważne miejsce.

Dobrą okazję na włączenie w obręb historii postaci Ahaswera mogłaby dawać także nigdy nieukończona przez pisarza Ucieczka Lotha (Wat 1989: 105-130). W notatnikach i maszynopisach znajduje się obszerny materiał, na podstawie którego można pokusić się o rekonstrukcję pierwotnego zamysłu powieści. Tomas Venclova zauważa, że istotnym komponentem dzieła prawdopodobnie byłaby tematyka religijna i relacja pomiędzy chrześcijaństwem a judaizmem

11 Formuła veloziferisch powstała z połączenia dwóch słów: Velaitas [pośpiech] i Luzifer [Lucyfer] (Osten 2005: 47).

12 Do tej postaci, pisząc o Ahaswerze, poeta już odnosił się w jednym z listów do żony (Wat 2005: 632). 
(Venclova 1997: 278). Sama powieść mogłaby w ostatecznym kształcie przybrać formę nieco zbliżoną do Doktora Faustusa Tomasza Manna i zawierać pogłębioną refleksję na temat faszyzmu i innych totalitaryzmów (w tym najważniejszego dla poety - stalinizmu) oraz ich źródeł w europejskiej tradycji (Venclova 1997: 269). Wat planował także wiele nawiązań do historii biblijnych (głównie związanych z Księgą Rodzaju). Być może figura Ahaswera okazałaby się tutaj przydatna, łącząc się z innymi kulturowymi figurami, do których poeta nawiązywał i przez których pryzmat interpretował także własny los, choćby ze Świętym Pawłem, który w lekturze Wata jest przede wszystkim zdrajcą własnej kultury.

\section{PODSUMOWANIE}

Realizacje motywu Ahaswera, które dotychczas pomijano w opracowaniach, pozwalają dostrzec inne ścieżki interpretacyjne i otworzyć twórczość Wata na nowe odczytania. Analiza przemian, jakim w twórczości Wata ulega wątek związany z Żydem Wiecznym Tułaczem, umożliwia analizę drogi poety od obserwacji zbiorowości do skupienia na losach pojedynczego człowieka. Czytanie literatury i kultury poprzez swoje życie daje możliwość odczuwania przynależności do kultury śródziemnomorskiej i jej wielowiekowego dziedzictwa.

Żyd Wieczny Tułacz w kolejnych dziełach autora Bezrobotnego Lucyfera przechodzi przemianę - choć wcześniej był postacią, której życie wpisywało się przede wszystkim we wspólnotowy wymiar żydowskiego losu, w późniejszych utworach polskiego poety staje się figurą egzystencji jednostki i biografii samego poety.

Obecne w twórczości intymistycznej poety nawiązania do postaci Żyda Wiecznego Tułacza pozwalają także na odczytanie Ahaswera jako jednej z ważnych figur nowoczesności. Szczególnie istotna wydaje się konieczność dokładniejszej analizy notatnikowych zapisów i podjęcia namysłu nad możliwymi odczytaniami postaci Żyda Wiecznego Tułacza przez pryzmat myśli Kierkegaarda.

Choć postać Ahaswera w twórczości Wata przechodzi różne przemiany, realizacja tego motywu nie wykracza nigdy poza ujęcia typowe dla modernizmu. Żyd Wieczny Tułacz jest dla poety figurą osoby, która nigdzie w świecie nie może znaleźć dla siebie miejsca. Mimo poczucia wyobcowania, a może właśnie z jego powodu Wat chętnie posługuje się językiem toposów kultury, wskazując na uniwersalne tęsknoty i pragnienia człowieka. Źródłem tych wykorzystywanych przez poetę figur jest oczywiście kultura śródziemnomorska, do której uniwersalnych narracji należy między innymi legenda o Żydzie Wiecznym Tułaczu.

\section{BIBLIOGRAFIA}

Anderson, George. 1965. The Legend of the Wandering Jew, Rhode Island: Brown University Press.

Berman, Marshall. 2006. „,Wszystko, co stałe, rozplywa się w powietrzu”. Rzecz o doświadczeniu nowoczesności, tłum. Marcin Szuster, Kraków: TAiWNP Universitas.

Bolecki, Włodzimierz. 2001. Od ,postmodernizmu” do „modernizmu” (Wat-inne doświadczenie), „Teksty Drugie”, 2: 29-39. 
Bowen, William Fredric. 1970. A survey of thematic interpretation of the Legend of the Wandering Jew in literature, https://archive.org/details/Bowen1970/mode/2up] [1.03.2020].

Graf, Paweł. 2018. Automobil w pędzie. Szkice o futuryzmie i futurystach, Poznań: Wydawnictwo Naukowe UAM, s. 274-300.

Kotarski, Henryk, Andrzej Kurbski ok. 1528-05.1583, w: Internetowy polski słownik biograficzny, https://www.ipsb.nina.gov.pl/a/biografia/andrzej-kurbski [3.01.2020].

Kuciel-Frydryszak, Joanna. 2012. Stonimski. Heretyk na ambonie, Warszawa: Wydawnictwo AB [plik mobi].

Leschnitzer, Adolf. 1986. The Wandering Jew. The Alienation of the Jewish Image, w: Galit Hasan-Rokem i Alan Dumoles (ed.), The Wandering Jew. Essays in the Interpretation of a Christian Legend, Bloomington: Indian University Press, s. 227-235.

Łukaszuk, Małgorzata. 1989. „...i w kołysanke przemieniony płacz...” Obiit... Natus est w poezji Aleksandra Wata, Londyn: Kontra.

Mazurkiewicz, Mariusz. 2005. Jednostka a absolut w filozofii Sörena Kierkegaarda, „Studia Redemptorystowskie", 3: 97-119.

Miłosz, Czesław. 2001. O wierszach Aleksandra Wata, w: tenże, Prywatne obowiazki, Kraków: Wydawnictwo Literackie, s. 79-94.

Nyczek, Tadeusz. 1988. Bach na dachu Łubianki (Aleksander Wat), w: tenże, Emigranci, Londyn: Wydawnictwo Aneks, s. 11-31.

Olejniczak, Józef. 1999. Aleksander Wat, w: tenże, Emigracje. Szkice, studia, sylwetki, Katowice: Agencja Artystyczna „Para”, s. 203-220.

Osten, Manfred. 2005. „Lucyferowy pośpiech”, czyli Goethe odkrywa zalety powolności. O nowoczesności pewnego klasyka w XXI stuleciu, przeł. Maria Krzysztofiak, Poznań: Wydawnictwo Poznańskie.

Panas, Władysław. 1996. Topika judajska w literaturze polskiej XX wieku, w: tenże, Pismo i rana. Szkice o problematyce żydowskiej w literaturze polskiej, Lublin: Wydawnictwo Dabar, s. 117-142.

Pietrych, Krystyna. 1999. O „,Wierszach śródziemnomorskich” Aleksandra Wata, Warszawa: Wydawnictwo IBL PAN.

Pietrych, Krystyna. 2017. Notatniki zamiast opus magnum?, „Teksty Drugie”, 4: s. 115-130.

Piotrowski, Wojciech. 1996. Legenda o Ahaswerze w literaturze polskiej, Słupsk: Wyższa Szkoła Pedagogiczna w Słupsku.

Piotrowski, Wojciech. 2008. Legenda o Ahaswerze - antologia tekstów, Piotrków Trybunalski: Naukowe Wydawnictwo Piotrkowskie.

Prokop-Janiec, Eugenia. 1992. „Żyd wieczny tułacz”. Dialektyka, publicystyka, katastrofa, „Teksty Drugie”, 5: 74-84.

Prokop-Janiec, Eugenia. 2001. Żyd-Polak-artysta. O budowaniu tożsamości po Zagładzie, „Teksty Drugie”, 1: 120-134.

Słonimski, Antoni. 1964. Poezje zebrane, Warszawa: Państwowy Instytut Wydawniczy.

Venclova, Tomas. 1997. Aleksander Wat. Obrazoburca, przeł. Jan Goślicki, Kraków: Wydawnictwo Literackie.

Wat, Aleksander. 1960. Bezrobotny Lucyfer, Warszawa: Czytelnik.

Wat, Aleksander. 1989. Ucieczka Lotha. Proza, Londyn: Oficyna Wydawnicza Margines.

Wat, Aleksander. 1990a. Dziennik bez samogłosek, Warszawa: Czytelnik. 
Wat, Aleksander. 1990b. Mój wiek. Pamiętnik mówiony, Warszawa: Czytelnik.

Wat, Aleksander. 1992. Poezje zebrane, Kraków: Znak.

Wat, Aleksander. 2005. Korespondencja, Warszawa: Czytelnik.

Wat, Aleksander. 2015. Notatniki, Warszawa: Wydawnictwo IBL PAN.

Wolff-Powęska, Anna. 2008. Żyd Wieczny Tułacz: legenda i rzeczywistość, „Przegląd Zachodni", 2: 21-44.

Żurek, Sławomir J. 2004. Synowie księżyca: zapisy poetyckie Aleksandra Wata i Henryka Grynberga w świetle tradycji i teologii żydowskiej, Lublin: Wydawnictwo Katolickiego Uniwersytetu Lubelskiego.

\section{THE WANDERING JEW (AHASWER) THEME IN LITERARY WORKS OF ALEKSANDER WAT. FROM THE FIGURE OF COLLECTIVITY TO THE INDIVIDUALITY SIGN}

The article analyses the Wandering Jew theme in literary works of Aleksander Wat. The author focuses on those texts which have been neglected by researchers analysing this theme. An important part of article is the analysis of Wat's notebooks and letters to his wife. The Wandering Jew theme in literary works of Aleksander Wat transforms from the figure of collectivity into the figure of individual fate. Moreover, Wat interprets Ahaswer by means of the writer's own life. Ahaswer in later works of Aleksander Wat begins to show a consciousness of gulit and has a need to make atonement. An attempt of interpreting Ahaswer's fate as a modernistic figure can be made on the basis of chronologically last Wat's texts pondering on the life of the Wandering Jew.

Keywords: modernity, Aleksander Wat, Wandering Jew, Ahaswer, Dreams from Mediterranean Sea, notebooks Aleksander Wat, letters Aleksander Wat

Zgłoszenie artykułu: 27.09.2020

Recenzje: 30.11 .2020

Rewizja: 31.12.2020

Akceptacja: 5.01 .2020

Publikacja on-line: 30.03.2021

(C) 2021 Autorka. Jest to publikacja ogólnodostępna, którą można wykorzystywać, rozpowszechniać i kopiować w dowolnej formie zgodnie z licencją Creative Commons CC-BY 4.0 